Web Site: https://jutq.utq.edu.iq/index.php/main

Email: journal@jutq.utq.edu.iq

\title{
"Relationship between serum adiponectin and apelin hormones with lipid profile in Basra pregnant women"
}

\author{
https://doi.org/10.32792/utq/utj/vol12/1/9
}

\section{*Hanaa, S.Kadhum.*,Taha, J. Al-Taha**, and Ali F.Al- Assady***}

*Ph.D. physiology, College of Science/Biology dep., **Prof. D. physiology, College of Agriculture, ***Ph .D. Gynecology, College of Medicine, University of Basra

\begin{abstract}
Pregnancy is associated with normal physiological changes that assist the nurturing and survival of the fetus. Changes in hormonal levels and biochemical levels, these adaptive changes which become very important in the event of complications. So the study was carried out with the objective to determine the levels of adiponectin and apelin and their relations with lipid profile (TC, TG and HDL) were investigated in present study in groups of Basra pregnant women during different months of pregnancy and the results were compared with non pregnant females as control group.In this study one hundred sixty healthy women ranging from 20 - 40 years old, out of them seventy pregnant and ninety females non-pregnant were considered as control group. The pregnant women attended the Gynecology units in the public state hospitals in Basra Governorate. The enzyme linked immunosorbent assay system (ELISA) was used to determine the serum apelin and adiponectin levels. Blood samples were taken from pregnant women at the end of each month of pregnancy and from control group. The results indicated that adiponectin and apelin levels decreased significantly $(\mathrm{p}<0.0001, \mathrm{p}<$ $0.01)$ respectively in pregnant women than non- pregnant women.On the other hand, accompanied by an increase significantly $(\mathrm{p}<0.0001)$ in the
\end{abstract}




\section{University of Thi-Qar Journal Vol.12 No.1 Mar 2017 \\ Web Site: https://jutq.utq.edu.iq/index.php/main \\ Email: journal@jutq.utq.edu.iq}

level of Lipid profile (TC, TG and HDL) concentration in pregnant women compared to non-pregnant women.

Pearson correlation analysis showed a high significant correlation between serum apelin and serum adiponectin level, in addition to both of them with Lipid profile. The finding suggests that serum apelin and adiponectin besides lipid profile.

\section{Introduction}

Pregnancy represents a serious challenge to all body systems. The progressive physiological changes that occur are essential to support and protect the developing fetus and also to prepare the mother for parturition. This causes no major problems for healthy women; however, certain factors can affect an individual's ability to adapt to the demands of pregnancy, such as maternal age and multiple gestations. In the presence of clinical or subclinical pathology, the normal physiological changes of pregnancy can place significant strain on already compromised systems, threatening the lives of both mother and fetus (King,2000). However, adipose tissue is no longer considered an inert tissue mainly devoted to energy storage but is now recognized as an active endocrine organ secreting several hormones and adverse range of other protein factors(Guerre, 2004). Furthermore, the role of adipose tissue as a metabolically active organ is rapidly expanding area of research discovery of cell-signaling proteins by adipocytes, termed adipokines, dispelled the belief that fat is a passive tissue functioning solely for energy storage and insulation. To date, over one hundreds adipokines have been identified so far (Trayhurn and Wood, 2004). In general, a number of proteins secreted by adipocytes or called adipocytokines. Leptin, adiponectin, visfatin, apelin and resistin( Berg and Scherer, 2005).

Adiponectin is a protein of 244-amino acids (30-kDa), secreted mainly.from adipocytes and plays an important role in the regulation of lipid and glucose metabolism (Karbowska and Kochan, 2006).It is highly abundant in human serum and known to circulate in several multimeric forms, which differ in biological activity (Arita et al., 1999; Pajvani et al., 2003; Waki et al., 2003). With regard to adiponectin in normal pregnancy, 


\section{University of Thi-Qar Journal Vol.12 No.1 Mar 2017 \\ Web Site: https://jutq.utq.edu.iq/index.php/main \\ Email: journal@jutq.utq.edu.iq}

maternal adiponectin secretion progressively declines during the course of pregnancy (MAJID KHANDOUZI1 et al., 2014). This decrease is associated with $60 \%$ reduction of adiponectin m RNA levels in whit adipose tisue (WAT) (Lanfranco et al., 2004).Moreover, adiponectin plays an important role in lipid metabolism, energy homeostasis, glucose regulation, and protection against the development of atherosclerosis (Yokota et al., 2000).

Apelin is a multifunctional peptide which is metabolized by the angiotensin - converting enzyme - related carboxy peptidase -2 (ACE-2), discovered from bovine stomach extracts in 1998, as an endogenous ligand for the orphan receptor APJ1 (Tatemoto et al., 1998). Recently tissue where is produced by adipocytes under the regulation of nutritional status (Kawamata et al., 2001). It is synthesized as a pre-pro-peptide or (prepropeptide) of 77 aminoacids, and shorter active forms, including aplein-12,13,16,17 and 36 aminoacids(Lee et al., 2000). Generally, apelin is a multifunctional peptide which is catabolized by the angiotensinconverting enzyme-related carboxypeptidase-2 (ACE2)( De Falco, et al., 2004). The peptide is well known for its hemodynamic effects and its role in energy and fluid homeostasis. Pregnancy is a state of dramatically altered maternal hemodynamic and metabolism, but the role of apelin is unknown (Masri et al., 2005). Though, apelin, a novel cardiovascular bioactive peptide and a circulatory paracrine hormone, is extensively distributed in a variety of tissues, including heart, lungs, kidney, central nervous system, and fatty tissues (Jia YX et al., 2007). However, several studies have shown the relationship between serum adiponectin and apelin with lipid levels (Geloneze, et al., 2009; Eynatten, et al., 2006). In most studies, the level of this hormone indicates an inverse relationship with the low triglycerides (TG) serum cholesterol; and a positive correlation with high density lipoprotein (HDL) (Matsubara, et al., 2006).

\section{Aim and recommendation}

In the literature, not a lot of available works has been published on apelin and its correlates to adiponectin, specifically in Basra pregnant women. Therefore, Because of the fundamental role of serum adiponectin level and apelin in chronic diseases and also the importance of dyslipidemia in 


\section{University of Thi-Qar Journal Vol.12 No.1 Mar 2017 \\ Web Site: https://jutq.utq.edu.iq/index.php/main \\ Email: journal@jutq.utq.edu.iq}

cardiovascular disease and metabolic syndrome, the aim of this study was to assessment the serum adiponectin and apelin concentration in pregnant women and showing the relationship between serum apelin level and serum adiponectin level besides lipid profile. 


\section{University of Thi-Qar Journal Vol.12 No.1 Mar 2017 \\ Web Site: https://jutq.utq.edu.iq/index.php/main \\ Email: journal@jutq.utq.edu.iq}

\section{Materials and Methods}

\section{Study population (Subjects)}

The study population comprised 180 women aged $20-40$ years. 70 apparently healthy pregnant women.Patient and a group of 90 healthy (non-pregnant) were included as a control group. The ages of the apparently healthy individuals were ranged from (21-50) years. They were collected from my college, medical staff and relatives who were free from signs and symptoms of any chronic diseases like diabetes, hypertension, and others.

These women were attended the Gynecology units in the governmental hospitals-Basra Governorate. These included: Ibn-Ghazwan.Al-Mawani, Al-Fayhaa and Basra General Hospital which drain most patients from Urban and rural areas. None of the selected women suffered from any type of disease. Required information were collected by the investigator depends on direct interview with women before being admitted to the study, using the questionnaire, in which includes information on age, parity, month of pregnancy, and geographical area. Exclusive criteria included current maternal diseases (diabetic, hypertension, and metabolic syndrome), smoking or drug use and non-fasting women.

\section{Sampling}

Venous blood samples $(10 \mathrm{ml})$ were drowning from pregnant and nonpregnant women. Each sample was put in test tubes $(8 \mathrm{ml})$ were used left for short time to allow blood clotting, then serum samples were obtained by centrifugation at room temperature at $3500 \mathrm{rpm}$ for 10 minutes. Serum cholesterol, triglyceride, high-density lipoprotein, and hormones (adiponectin and apelin) were determined.

\section{Biochemical assays}

Serum samples were analyzed for concentrations of serum total cholesterol, triglycerides, and HDL-cholesterol levels. Serum total cholesterol, triglycerides and HDL concentrations were measured enzymatically using (Biolabo- France). Serum adiponectinand apelin was assayed by Human adiponectin and apelin-c terminus Elisa - Kit (DRG- 


\section{University of Thi-Qar Journal Vol.12 No.1 Mar 2017 \\ Web Site: https://jutq.utq.edu.iq/index.php/main \\ Email: journal@jutq.utq.edu.iq}

Germany). Both hormones were determined in duplicate and were run in the same assay in each period.

\section{Statistical analysis}

Data are presented as means \pm S.D. Differences among study groups were assessed through Student's t-test when data were normally distributed was used to determine the significance among groups (Landan of Brian and Everit, 2004).

The results in this study were accepted as statistical significant when the $P$ value less than $(\mathrm{p}<0.05)$.

\section{Results}

As show in table (1), results revealed that adiponectin and apelin hormones were significantly decreased $(\mathrm{p}<0.0001)$ in comparison with non-pregnant group.

On the other hand, Data were indicated that profile lipid (HDL, Cholesterol, and TG) of pregnant group were significantly increased at ( $p$ $<0.0001$ ) in comparison of non-pregnant (control group) (Table 1).

On the other hand, to assess the relationship between the level of adiponectin and apelin hormones in pregnant women. The linear regression analysis was used to evaluate the data. The results indicated that adiponectin as a dependent variable, had an inverse correlation between adiponectin and apelin (- 0.2016).While, interestingly, both of those two hormones have been inversely relation with (TG, HDL, CHO). Conversely, results appeared positive association of adiponectin to (HDL) (Table 2).

\section{Discussion}

The result of this study shows that the pregnant women had significantly lower adiponectin concentration $(\mathrm{P}<0.0001)$ than control group. However, little is known about the role of this hormone during pregnancy. Only a few studies concerning adiponectin in pregnancy have been published (Jens, et al.; 2006). In contrast, to our observation of decreasing levels of adiponectin (Worda, et al.; 2004) who reported adiponectin 


\section{University of Thi-Qar Journal Vol.12 No.1 Mar 2017 \\ Web Site: https://jutq.utq.edu.iq/index.php/main \\ Email: journal@jutq.utq.edu.iq}

levels reached statistical significance in a study using single measurements from pregnant normal and gestation diabetic mallietus (GDM) women over a range of gestational ages. Nevertheless, most of studies, observed with decrease in adiponctin along pregnancy(combs, et al., 2003). A possible justification for this alleged discrepancy may be an alteration in adiponectin regulation during conception. Adiponectin expression and secretion have been shown to be subjected to regulation by numerous Factors, some of which are affected by the unique hormones list of pregnancy. This hypothesis is supported by studies in mice, which propose that estrogen, prolactin and testosterone (all increased in normal human pregnancy) may be affected adiponectin level (combs, et al., 2003; Gavrila, et al ; 2003 ). The results of this study are in the line with previous observations (Cseh, et al; 2004; Kajanti, et al; 2005).Ultimately, elucidation of adiponectin physiology in the setting of both normal pregnancy and in pathologic condition may provide unique insight in to fundamental processes that are relevant to health and disease in mother and child (Retnakaran, 2012).

On the other hand, serum apelin level has lower significantly $(\mathrm{P}<0.01)$ in pregnant fetus women compared to the control group. However, apelin has a wide spread pattern of expression in human tissues and it is produced in several tissues of the body, including brain, lung, pregnancy and lactation breast (Defalco et al., 2002; O' carroll et al., 2000). Like many other requlatory peptides, pharmacological studies indicate that apelin have multiple biological activites. Previously published investigations appeared significantly lower levels of apelin in diabetes compared to healthy control group. (Zhang, et al; 2009; Erdem, et al;2008). These finding were in accord with our results. In the present study, the results showed that lipid profile (cholesterol, triglyceride and HDL) during pregnancy, compared with those non-pregnant women of higher significantly $(\mathrm{P}<0.0001)$ of every one of them, compared to nonpregnancy women, these finding were agreement with (Teresa, et al ; 2007 ; salisu and Atiku, 2009 ; prachwaiu and patel, 2011). Furthermore, some previous studies in normal pregnancy appeared that the most dramatic damage in the lipid and lipoprotein profile is serum 


\section{University of Thi-Qar Journal Vol.12 No.1 Mar 2017 \\ Web Site: https://jutq.utq.edu.iq/index.php/main \\ Email: journal@jutq.utq.edu.iq}

triglycesidemia (De, J et al; 2006). This results corroborates with the earlier discovery (Udoh et al; 2002) who noticed forward- looking increase in serum TC, TG, HDL at different stages of pregnancy. Present finding are also in agreement with the observations of (Rebuffe et al; 1985), who noticed that lipid deposition raise with advance pregnancy, whereby in late pregnancy lipolysis and fat mobilization increased, due to the mobilization of lipid stores plasma fatty acids and glycerol concentration is increased, also in late pregnancy HCS promote lipolysis and fat mobilization. While in the early productive due to the increased production of Estradiol, progestrone and insulin lipid deposition and lipolysis is inhibited (Rebuffe et al; 1985).

The principle organizer of this hypertriglyceridemic is estrogen as associated with hyper estrogenaemia (Emeka, et al; 2012). Other investigators explain that process may be modulated by hyperinsulinemia found in pregnancy (Adegke, et al., 2003).

Interestingly, in the present study serum adiponectin levels were negative significant correlated with each of $\mathrm{TC}$, TG and positive significant correlated with HDL. These findings agree with those of (Chan, et al., 2005; Cnop, et al., 2003) that they reported that the associations between plasma adiponectin and lipid concentrations had dependent degree of obesity. Also, these findings agree with those of (Bugianesi et al., 2005)A positive relationship of adiponectin with HDL and a negative relationship with triglycerides and total cholesterol have been reported in many studies (Tschritter, et al., 2003; Chan, et al., 2005; Cnop, et al., 2003; Baratta, et al., 2004).

Table (1): Level of adiponectin, apelin hormones, Lipid profile (TC, TG, HDL) in Non-pregnant (control) and pregnant women groups. Values were expressed as (mean $\pm \mathrm{SD})$.

\begin{tabular}{|l|l|l|l|}
\hline parameters & $\begin{array}{l}\text { Non-pregnant } \\
\text { (control) } \\
(\mathbf{n = 9 0})\end{array}$ & $\begin{array}{l}\text { Pregnant } \\
\text { Women } \mathbf{( 7 0 )}\end{array}$ & P - value \\
\hline Adiponectin (ng/ml) & $7.764 \pm 2.035$ & $6.091 \pm 1.966$ & 0.0001 \\
\hline
\end{tabular}




\section{University of Thi-Qar Journal Vol.12 No.1 Mar 2017}

Web Site: https://jutq.utq.edu.iq/index.php/main

Email: journal@jutq.utq.edu.iq

\begin{tabular}{|l|l|l|l|}
\hline & & & \\
\hline Apelin (pg/ml) & $\begin{array}{l}125.153 \pm \\
42.886\end{array}$ & $\begin{array}{l}118.746 \pm \\
41.548\end{array}$ & 0.01 \\
\hline HDL (mmol / L) & $1.062 \pm 0.549$ & $1.474 \pm 0.582$ & 0.0001 \\
\hline TC(mmol/L) & $4.599 \pm 0.665$ & $5.984 \pm 1.447$ & 0.0001 \\
\hline TG (mmol/L) & $1.634 \pm 0.559$ & $3.312 \pm 1.027$ & 0.0001 \\
\hline
\end{tabular}

Table (2): linear regression analysis between serum adiponectin and apelin hormonesto Lipid profile (TC, TG, HDL) in pregnant women.

\begin{tabular}{|l|l|l|}
\hline Variables & Adiponectin & Apelin \\
\hline Adiponectin (ng/ml) & 0.0 & -0.20151 \\
\hline Apelin (pg/ml) & -0.20161 & 0.0 \\
\hline CHO $(\mathbf{m m o l} / \mathbf{L})$ & -0.42276 & 0.09163 \\
\hline TG(mmol/L) & -0.49217 & 0.20175 \\
\hline HDL $(\mathbf{m m o l} / \mathbf{L})$ & 0.00162 & -0.11889 \\
\hline
\end{tabular}

\section{References}

1. Adegke, O.A.; Iyare, E.E. and Gbenebitse S.O. (2003). (Fasting plasma glucose and cholesterol

levels in Pregnant Nigerian Women). Niger. Postgrad. Med. J. 10(1), 32-36.

2. Arita Y, Kihara S, Ouchi N, Takahashi M, Maeda K, Miyagawa J, Hotta K, Shimomura I, Nakamura T, Miyaoka K, Kuriyama H,Nishida M, Yamashita S, Okubo K, Matsubara K, Muraguchi M, Ohmoto Y, Funahashi T, Matsuzawa Y (1999).(Paradoxical decrease of an adipose-specific protein, adiponectin, in obesity). Biochem Biophys Res Commun. 257(1):79-83.

3. Baratta R, Amato S, Degano C, Farina MG, Patanè G, Vigneri R, et al. 2004. (Adiponectin relationship with lipid metabolism is 


\section{University of Thi-Qar Journal Vol.12 No.1 Mar 2017}

Web Site: https://jutq.utq.edu.iq/index.php/main

Email: journal@jutq.utq.edu.iq

independent of body fat mass: Evidence from both cross-sectional and intervention studies). J Clin Endocrinol Metab;89:2665-2671.

4. Berg AH, Scherer PE. 2005. (Adipose tissue, inflammation, and cardiovascular disease). Circ Res.;96:939-949

5. Bugianesi E, Pagotto U, Manini R, et al. 2005. (Plasma adiponectin in nonalcoholic fatty liver is related to hepatic insulin resistance and hepatic fat content, not to liver disease severity). J Clin Endocrinol Metab.; 90(6):3498-504.

6. Carroll, A.M.; Selby, T.L.; Palkovits, M., and Lolait, S.J. (2000). (Distribution

of mRNA encoding B78/apj, the rat homologue of the human APJ receptor, and its

endogenous ligand apelin in brain and peripheral tissues). Biochim. Biophys.

Acta 1492, 72-80.

7. Chan DC, Watts GF, Ng TW, Uchida Y, Sakai N, Yamashita S, et al. 2005. (Adiponectin and other adipocytokines as predictors of markers of triglyceride-rich lipoprotein metabolism). Clin Chem ;51:578-585.

8. Cnop M, Havel PJ, Utzschneider KM, Carr DB, Sinha MK, Boyko EJ, et al. 2003. (Relationship of adiponectin to body fat distribution, insulin sensitivity and plasma lipoproteins: evidence for independent roles of age and sex). Diabetologia;46:459-469

9. Combs, T.P.; Berg, A.H.; Rajala, M.W., et al.(2003). (Sexual differentiation, pregnancy,

calorie restriction, and aging affect the adipocyte-specific secretory protein adiponectin). Diabetes.,

52: 268-276.

10. Cseh K, Baranyi E, Melczer Z, Kaszas E, Palik E, Winkler G. 2004. (Plasma adiponectin and pregnancy-induced insulin resistance). Diabetes Care; 27: 274-275. | PubMed

11. De Falco M., Fedele V., Russo T., Virgilio F., Sciarrillo R., Leone S.,Laforgia V. and De Luca A. 2004. (Distribution of apelin, the 


\section{University of Thi-Qar Journal Vol.12 No.1 Mar 2017}

Web Site: https://jutq.utq.edu.iq/index.php/main

\section{Email: journal@jutq.utq.edu.iq}

endogenous ligand of the APJ receptor, in the lizard Podarcis sicula).J. Mol. Histol. 35, 521-527.

12. De J, Mukhopadhyay A, Saha P. 2006. (Study of serum lipid profile in pregnancy induced hypertension).Indian $\mathrm{J}$ Clin Biochem. ;21:165-8. [PMC free article] [PubMed]

13. Emeka E. Neboh, John K. Emeh, Uzo U. Aniebue, Ebele J. Ikekpeazu, Ignatius C. Maduka, a

nd Frank O. Ezeugwu n. 2012. (Relationship between lipid and lipoprotein metabolism in trimesters

of pregnancy in Nigerian women: Is pregnancy a risk factor?) J Nat Sci Biol Med. 3(1): 32-37.

14. Erden; Dogni, T.; Tasci, I.( 2008). (Low plasma apelin levels in newly diagnosed type 2).

Experimental and clinical endocrinology and diabetes,116; 289292.

15. Eynatten MV, Hamann A, Twardella D, Nawroth PP, Brenner H, Rothenbacher D.2006. (Relationship of adiponectin with markers of systemic inflammation, atherogenic dyslipidemia, and heart failure in patients with coronary heart disease). Clin Chem;52:853-9.

16. Gavrila A, Chan JL, Yiannakouris N, Kontogianni M, Miller LC, Orlova C, et al. 2003. (Serum adiponectin levels are inversely associated with overall and central fat distribution but are not directly regulated by acute fasting or leptin administration in humans: Cross-sectional and interventional studies). J. Clin. Endocrinol. Metab. ;88:4823-4831

17. Geloneze B, Pereira JA, Pareja JC, Lima MM, Lazarin MA, Souza IC, et al. 2009. (Overcoming metabolic syndrome in severe obesity: Adiponectin as a marker of insulin sensitivity and HDL-cholesterol improvements after gastric bypass). Arq Bras Endocrinol Metabol;53:293-300. 


\section{University of Thi-Qar Journal Vol.12 No.1 Mar 2017 \\ Web Site: https://jutq.utq.edu.iq/index.php/main \\ Email: journal@jutq.utq.edu.iq}

18. Guerre-Millo M. 2004. (Adipose tissue and adipokines: for better or worse). Diabetes Metab.;30(1):13-19.

19. Jens, F., Christian S., Jan F., Allan, F. and Per, O. 2006. (A longitudinal study of serum adiponectin during normal pregnancy). BIOG.. 113: 110-113.

20. Jia YX, Lu ZF, Zhang J, Pan CS, Yang JH, Zhao J, Yu F, Duan XH, Tang CS, Qi YF. 2007. (Apelin activates L-arginine/nitric oxide synthase/nitric oxide pathway in rat aortas) . Peptides.; 28: 2023-9.

21. KarboOwska, J. \& Kochan, Z. (2006). (Role of adiponectin in the regulation of carbohydrate and lipid metabolism). J Physiol Pharmacol, 57 Suppl 6, 103-13.

22. Kawamata, Y., Habata, Y., Fukusumi, S., Hosoya, M., Fujii, R., Hinuma, S., ishizawa, N., Kitada C., Onda, H., Nishimura, O., and Fujino, M. (2001). (Molecular properties of apelin: tissue distribution and receptor binding). Biochim Biophys Acta 1538, 162-171.

23. King JC. 2006. (Maternal obesity, metabolism, and pregnancy outcomes). AnnuRev Nutr; 26:271-91.

24. Lanfranco F, Zitzmann M, Simoni M \& Nieschlag E. , 2004. (Serum adiponectin levels in hypogonadal males: Influence of testosterone replacement therapy). Clinical Endocrinology (Oxf) 60, 500-507.

25. Majid Khandouz11 \& Manab deka2. 2014. ( The role of adiponectin in human pregnancy; International Journal of Research inEngineering \& Technology). (impact: IJER) ISSN(E): 2321-8843; ISSN(P): 2347-4599 Vol. 2, Issue 3, , 93-100. 20.

26. Masri B, Knibiehler B, Audigier Y. 2005. (Apelin signalling: a promis- ing pathway from cloning to pharmacology). Cell Signal.;17(4):415-426. 


\section{University of Thi-Qar Journal Vol.12 No.1 Mar 2017 \\ Web Site: https://jutq.utq.edu.iq/index.php/main \\ Email: journal@jutq.utq.edu.iq}

27. Matsubara M, Maruoka S, Katayose S. 2002. (Decreased Plasma Adiponectin Concentrations in Women with Dyslipidemia). J Clin Endocrinol Metab;87:2764-9.

28. Pajvani UB, Du X, Combs TP, Berg AH, Rajala MW, Schulthess T, Engel J, Brownlee M, Scherer PE 2003.(Structure-function studies of the adipocyte-secreted hormone Acrp30/adiponectin. Implications for metabolic regulation and bioactivit). J Biol Chem. 278:9073-9085.

29. Parchwani D and Patel D .2011: (status of lipid profile in pregnancy). NationalJournal of

Medical Research. Vol. 1(1). .7.

30. Rebuffe, S.M.L. ; Enk, and N, Crona. 1985. (Fat cell metabolism in different region in women.

Effect of menstrual cycle, pregnancy and lactation). J clin invest. 75: 1973 - 1976.

31. Retnakaran, A.1 ; Retnakaran, R. 2012. (Adiponectin in pregnancy: implications for health and disease). Curr Med Chem. 19(32):5444-50.

32. Sabin, landan of Brian, and Everit, S.(Edit). 2004. A Handbook of statistical analyses lesing SPSS, chapman of Hell CRC, wasington.

33. Salisu A.I. and Atiku M.K. 2009: (Serum lipid profile in nonpregnant andpregnant hausa-fulani women at second and third trimesters of pregnancy in Kuralocal govenment area, Kano State, Nigeria). Bayero Journal of pure and AppliedSciences, 2(2): 131133

34. Tatemoto, K., Hosoya, M., Habata, Y., Fujii, R., Kakegawa, T., Zou, M.X., Kawamata, Y., Fukusumi, S., Hinuma, S., Kitada, C. et al. 1998. (Isolation and characterization of a novel endogenous peptide ligand for the human APJ receptor). Biochem Biophys Res Commun 251,471-476..

35. Teresa, S.P.; Barbara, E.; Mammel, M.M.; Nicrlas, C.; Fernando, S.; Catalin, H. , and Pablo, A. 


\section{University of Thi-Qar Journal Vol.12 No.1 Mar 2017 \\ Web Site: https://jutq.utq.edu.iq/index.php/main \\ Email: journal@jutq.utq.edu.iq}

2007. (serum adiponectin and lipid concentration in pregnant women with PCOS). human

Reproduction, 22: PP; 1830-1836.

36. Trayhurn P, Wood IS. 2004. (Adipokines: inflammation and the pleiotropic role of white adipose tissue). Br J Nutr.;92(3):347-355.

37. Tschritter O, Fritsche A, Thamer C, Haap M, Shirkavand F, Rahe $\mathrm{S}$, et al. 2003. (Plasma adiponectin concentrations predict insulin sensitivity of both glucose and lipid metabolism). Diabetes ;52:239-243.

38. Udoh, A. ; Ndem, E. ; Itam, E. ; Odigwe, C. ; Archibong, E. 2002. (Studies on cholesterol

profiles at various stages of pregnancy). Niger $J$ Intern Med. ,3:26-34.

39. Waki H, Yamauchi T, Kamon J, Ito Y, Uchida S, Kita S, Hara K, Hada Y, Vasseur F, Froguel P, Kimura S, Nagai R, Kadowaki T. 2003.(Impaired multimerization of human adiponectin mutants associated with diabetes. Molecular structure and multimer formation of adiponectin). J Biol Chem. 278:40352-40363.

40. Worda, C. ; Leipold, H. ; Gruber, C. ; Kautzky-Willer, A. ; Knofler, M. ; Bancher- Todesca, D.

2004. (Decreased plasma adiponectin concentrations in women with gestational diabetes mellitus).

Am J Obstet Gynecol .,191(6): 2120-2124.

41. Yokota $T$, Oritani K, Takahashi I, Ishikawa J, Matsuyama A, Ouchi N, Kihara S, Funahashi T, Tenner AJ, Tomiyama Y,Matsuzawa Y 2000.(Adiponectin, a new member of the family of soluble defense collagens, negatively regulates the growth of myelomonocytic progenitors and the functions of macrophages). Blood. 96(5): 1723-1732.

42. Zhang, Y. ; hen, C. ; Li, X. 2009. (in Chinese Diabetes people) . Diabetes care,32,e150. 